\title{
A More Excellent Way: Recovering Mystery in COVID Care
}

\author{
Joshua D. Genig ${ }^{1}$ \\ Published online: 30 May 2020 \\ ๑) Springer Science+Business Media, LLC, part of Springer Nature 2020
}

\begin{abstract}
This article explores the fundamental role of mystery in the care of patients suffering from COVID-19. Specific attention is paid to the disparity between modern and post-modern approaches to mystery and how medical instruction and care has often been conducted in the vein of the former. However, with post-moderns now being trained as medical clinicians and serving on the frontlines of this pandemic, there is an opportunity to return to a more ancient manner of understanding humanity, one which places mystery on equal footing with chemistry.
\end{abstract}

Keywords COVID-19 $\cdot$ Modern(ism) $\cdot$ Mystery $\cdot$ Post-modern(ism)

The modern world, for all its good, has failed us. There is a lot to unpack in that assertion, beginning with the very definition of "modern world." What is the modern world? What does it mean to be modern? As one might expect, the specific delineation of the modern period is as varying as those who dare to offer a timeline. What tends to be more congruent, however, are some of the key characteristics of this era. Things such as: the belief in progress and the move toward secularization, so prominent in the eighteenth-century Enlightenment; the promotion of individual rights and freedoms, evident in the Déclaration des droits de l'homme et du citoyen and the overarching thrust of the French Revolution; and the scientific revolution of the seventeenth century, which laid the groundwork for the singular place of honor shown to rational investigation (Taylor 1996).

It is this broad-sweeping, multi-century encompassing way of living and being and thinking that constituted the modern world. The question before us, though, is this: Has this modern world kept its promises? I would suggest that it has not, and that this reality could not be clearer than it is right now, amid the COVID-19 pandemic.

Joshua D. Genig

Joshua.genig@gmail.com; jgenig@med.umich.edu

1 Department of Spiritual Care, University of Michigan Hospital and Health Systems, 1500 E.

Medical Center Dr., Ann Arbor, MI 48109, USA 
The fundamental promise of the modern world was simple: It promised us that science and technology could save us-save our patients, save our jobs and even, at times, save our souls. As noted by Taylor, this way of thinking was prevalent at the time of the Enlightenment, and it remained our common existential hermeneutic throughout much of the eighteenth, nineteenth and twentieth centuries. Moreover, "by the beginning of the twentieth century, the notion of progress was closely linked with technological development, and that linkage intensified in the following decades" (National Academy of Sciences 1993). Princeton philosopher Diogenes Allen put a finer point on it when he observed that "modern science and technology so improved life that they led to a belief in progress, and in time to a belief in inevitable progress" (1993). Did this, however, really take place? Are we at the point of improved life and inevitable progress?

Indeed, there has been progress, but not all progress was or is good progress. Today, we might well be able to treat cancer better than we did in previous generations, but we can also harm people in ways we never imagined: the imprisonment of people with mental health issues instead of adequate treatment, the overprescribing of opioids when the effects are proven and deadly, and the forced isolation of our most vulnerable humans as they suffer from terrible viruses and are left to die alone. The point is that just because we are smarter does not mean we are better, nor does it mean that our lives are fundamentally improved.

Nevertheless, amid all the hope for progress and a better way of life, a dramatic cultural shift took place in the rapidly changing early stages of the twentyfirst century. This shift included a move away from the desire for revolution and rationality, so characteristic of the modern world, toward a more post-modern direction, encompassing all aspects of human life. Here, again, definitions are critical. What does it mean to be post-modern?

Like the numerous definitions of the modern world, those of post-modernism are many in number. However, all of them hold to some fundamental commonalities. First, post-modernism tends to rebuke the pragmatism of the modern era. Second, post-modernism seeks to recover uniquely "premodern ways of knowing, being and doing" (Smith 2006). These ways of knowing, being and doing are inherently ancient or, as Burrell notes, "anti-antimedieval" (2004), insofar as post-modernism shares the medieval opinion regarding the insufficiency of reason and rationality (see Trakakis 2006). One would expect, therefore, that the previous era's approach with a seemingly singular focus on rationality in the scientific and medical process would shift as well, but it seems as though it never did. Why?

Sally Rockey, from the NIH office of Extramural Research offered this compelling observation regarding the age of those leading the research medical field:

In more recent years, you see fewer people entering the faculty at ages 28 and below, and very few people receiving an R01 award before age 33. But, the biggest difference is seen at the later ages. The elimination of mandatory retirement during the $80 \mathrm{~s}$ and increasing life expectancy allowed people to remain employed much longer. We also suspect that the current economic situation is forcing many people to reconsider their retirement" (2012). 
What this indicates, at least at a high level, is that those teaching our newest medical students are not getting younger, but older. Pedagogically, therefore, one might well anticipate that many of the hold-over views of the world and humanity, so prevalent in the modern era, are still being propagated today, even though the students coming up through the ranks at present are not like their modern teachers. What are they like?

The Pew Research Center identifies this new generation of humans as those born between 1981 and 1996, those who are 24-39 in 2020 (Dimock 2019), indicating that medical students today are firmly entrenched in this post-modern/millennial world. And for all the misconceptions about this generation of women and men [that, among other things, they are lazy and cannot leave their parents' basement (Beaton 2016)] they are also known by one dominant truth: they are given to that which is ancient, to that which came well before them and their immediate predecessors. This reality is clearly envisaged in the general post-modern disdain for metanarratives, as first explained by the French philosopher, Jean-François Lyotard in his seminal work: The Post-modern Condition. In it, he defined post-modernism as specifically "incredulity toward metanarratives," which are grand stories that attempt to prove or legitimate themselves "by an appeal to universal reason" (Lyotard 1984; Smith 2006). Rather, post-modernism is drawn to narrative and myth, ways of telling stories that do not need legitimacy to have an impact or even to be true. All of life, in fact, becomes a story that is being told in real time. However, because it cannot be proven or legitimated, this story is inherently mysterious. As is the case with all mysteries of life, the more we live this story, the more mysterious it becomes. Thus, the natural pull of the post-modern's life is toward mystery and a way of living, being and doing that looks more like the first century than it does the twentieth century (Evans 2015).

Post-moderns are drawn to those people and places and beliefs that far extend the boundaries of our limited, present existence and comprehension, precisely because individual, autonomous rationality and understanding is not believed to be the limit of reality. Consequently, post-moderns are likewise drawn to ways of viewing the world that are congruent with all of the prominent, historical religions of the West, because each of these ancient religions hold fast to an understanding of humanity as intrinsically mysterious and beyond comprehension.

The most ancient Jewish tradition of interpretation of the creation of humanity asserts that the plural of Genesis 1:26 ("Let us make...") "signaled that God consulted [...] someone or something, while creating the human race" (Oseka 2018). And in looking to "someone or something" else, woman and man were "created as a bridge between 'upper' beings and 'lower' beings, namely, between spiritual beings [...] and animals" (ibid.). Thus, it was believed that individual human life was of the same value as "the whole humankind" (ibid.). In short, a single human life was humanity in one.

The Qur'an, also, recounts that God made Adam, "with [His] two hands" (38:75). And as the exegetes have commented, the significance of this reality is that "his [Adam's] creation was without the intermediary of a father or a mother. Also, [that] he constitutes a small creation within which the entire wider creation is contained" (Shakir 2018). Humanity is inherently mysterious, then, because 
humanity constitutes an embodied creation wherein all of creation finds its summation in a single human being.

And the Christian tradition, especially in its earlier iterations, proposes the same reality. Gregory of Nazianzen (Gregory the Theologian, as he is called) noted that the soul of a human being "is 'a part of God' [...], a 'breath of God', "a piece broken from the invisible Deity'" (380-81). Humanity is, very simply, "God weighed down by [a person's] bodily nature” (Lossky 1944/1998).

Given the entirety of the foregoing, however, we run into this conundrum and challenge with each-and-every patient encounter: we treat patients based upon their chemistry because that is what our modern education taught us, but what is speaking loudest in these patients is their inherent mystery. We believe that by thinking harder and deeper about matters of science, our patients will be saved from disease and death, but what patients are demonstrating is that they are not problems to be solved, but mysteries to be engaged. And this can be seen so very clearly in the present COVID-19 pandemic.

Today, we are in uncharted territories. Hospitals are overwhelmed, if not with patients, at least with chaos and death. Frontline heroes are being pushed to the point of breaking and some, sadly, have even ended their own lives in an attempt to halt the personal pain of it all (Watkins et al. 2020). As a nation and a medical community, we believe that we must find a solution to this problem, that modern science must meet this once-in-a-lifetime virus and defeat the enemy, which is the resultant death to which it so easily leads.

Yet, in this current epidemiological milieu and with the pressure to prevent death at all cost, what we have been most successful at, sadly, is reducing patients to objects, especially in the absence of family and friends at bedside. This, however, ought not to surprise us because if modernism (especially the Enlightenment) did one thing for humanity's view of the divine it was that it made God into an object, discernable only through the scientific method (Shuman and Meador 2003). Moreover, if humanity is made in the image of the divine, as the JudeoChristian scriptures make plain, and as other world religions so freely and deeply believe, then would not the same hold true for the humanity now suffering from this deadly virus? Have not our patients likewise become objects?

To that end, if infected patients have become like objects to be tested and prodded and poked and, hopefully, saved, then what does that make of us, the medical clinicians of all disciplines? It seems that it has left us all, from doctors and nurses and techs and respiratory therapists and social workers and environmental services to chaplains, in a position of acting more like scientists in a laboratory than pilgrims on our own journey, but a journey that comes alongside the other nonetheless. Thus, from my own area of expertise, because chaplains are only permitted on COVID floors in rare and extreme circumstances, we have become truly essential only when the various rites associated with healing and death are requested or required, relegating spiritual care to a very modern kind of functionality. The goal is not to enter into the story and the suffering of those for whom we care, but to check the boxes, as it were, assuring ourselves that we did all that was necessary, but not all we possibly could. This is equally true with medical 
clinicians where trials and experimental treatments are discussed and debated and the question "How can we heal?" looms over every encounter.

Of course, healing ought to be the primary goal. However, humans are more than flesh and bones that need to be healed. Nevertheless, within the context of this current viral pandemic, the human person has often been separated from the disease that afflicts her or him. In turn, the focus within medical and spiritual care is often on the disease and not the person, creating a depersonalizing effect (see Larchet 2002). Consequently, human beings, OUR PATIENTS (!), are pushed toward objectification, being relegated to psycho-somatic organisms, wherein the only thing that matters is their disease. All of this places us squarely in the trajectory of the modern era and the modern approach.

In reality, however, the goal of all medical care, not only amid this post-modern generation but from its very origin, is to help everyone involved acknowledge and experience the sacred, as the very "art" of medicine itself is to be "guard[ed]... in holiness" (Miles 2004). Admittedly, a previous generation of medical clinicians might well have seen this as nonsensical, but there seems to be the possibility of renewed appreciation for this work from within the cadre of the newest physicians, nurses, PAs, techs and all others involved in the care of sacred humanity-in no small way because many of them are being fast-tracked to certification and thrown into the trenches.

Humans are a mystery, yes. Moreover, since this mysteriousness and incomprehensibility are part of our very being - we are not just flesh and blood and we are not just the disease that affects us - then they ought to be factored significantly into the care given and received as well. Put simply, the care we offer in these days of great trial and tribulation ought to remember, first and foremost, that the relationships we are creating with our patients have "within [them] the full potential of an ever-deepening relationship with the Ultimate Other" (Hinshaw 2013). Healing may be found in trials and treatments, but if that is our only metric for success, then not every patient will end up being a victory. However, when our focus is on the mystery of the person for whom we are caring, as much as the symptoms with which they present themselves to us, then every encounter-whether it ends in life or deathhas the possibility of being a win.

\section{References}

Allen, D. (1993). The end of the modern world: A new openness for faith. Princeton Seminary Bulletin, 11, 11-31.

Beaton, C. (2016). 6 millennial myths that need to finally die. Forbes, 6 September.

Burrell, D. (2004). Faith and freedom: An interfaith perspective. Oxford: Blackwell.

Dimock, M. (2019). Defining generations: Where millennials end and generation Z begins. Pew Research Center, 17, 1-17.

Gregory Nazianzen, Orations in Ellverson, The dual natures of man.

Held Evans, R. (2015). Want millennials back in the pews? Stop trying to make church 'cool.' Washington Post, 30 April.

Hinshaw, D. (2013). Suffering and the nature of healing. Crestwood, NY: St. Vladimir's Seminary Press. Kaye, E. C. (2020). Finding faith. JAMA, 323(7), 609-610. 
Larchet, J.-C. (2002). The theology of illness. Crestwood, NY: St. Vladimir's Seminary Press.

Lossky, V. (1944/1998). The mystical theology of the eastern church. Crestwood, NY: St. Vladimir's Seminary Press.

Lyotard, J.-F. (1984). The postmodern condition: A report on knowledge. Minneapolis, MN: University of Minnesota Press.

Miles, S. H. (2004). The Hippocratic Oath and the ethics of medicine. New York: Oxford University Press.

National Academy of Sciences, National Academy of Engineering, and Institute of Medicine. (1993). Science and technology in modern society in Science, technology, and the federal government: National goals for a new era (pp. 9-16). Washington, DC: The National Academic Press.

Nazianzen, G. Poem, \& Poem on the soul in Ellverson, A-S. (1981). The dual nature of man: A study in the theological anthropology of Gregory of Nazianzus. Stockholm: Uppsala University, Almqvist \& Wiksell International.

Oseka, M. (2018). History of the Jewish interpretation of Genesis 1:26, 3:5, 3:22 in the middle ages. Scriptura, 117(1), 1-24.

Rockey, S. (2012). Age distribution of NIH principal investigators and medical school faculty. Extramural Nexus, 13 February.

Shakir, Z. (2018). The human in the Qur'an. Renovatio. The Journal of Zaytuna College, 5 June.

Shuman, J. J., \& Meador, K. G. (2003). Heal thyself: Spirituality, medicine, and the distortion of Christianity. Oxford: Oxford University Press.

Smith, J. (2006). Who's afraid of postmodernism: Taking Derrida, Lyotard, and Foucault to church. Grand Rapids, MI: Baker Academic.

Taylor, P. J. (1996). What's modern about the modern world-system? Introducing ordinary modernity through world hegemony. Review of International Political Economy, 3(2), 260-286.

Trakakis, N. (2006). Review of faith and freedom: An interfaith perspective by David Burrell. The Philosophical Quarterly (1950-), 56(225), 632-634.

Watkins, A., Rothfeld, M., Rashbaum, W. K., \& Rosenthal, B. M. (2020). Top ER doctor who treated virus patients dies by suicide. New York Times, 27 April.

Publisher's Note Springer Nature remains neutral with regard to jurisdictional claims in published maps and institutional affiliations. 